\title{
ACRL awards for 1997
}

By Jack Briody

\section{Honoring accomplishments and supporting professional development}

1.

CRL provides opportunities to recognize important contributions to the field of academic or research librarianship through the ACRL Awards Program. The ACRL Board of Directors, with the help of vendors and hard work from ACRL members, provides support for these recognition opportunities. ACRL currently has 15 awards in three categories: Achievement and Distinguished Service Awards, Research Awards/Grants, and Publications.

These opportunities are made available thanks largely to the ongoing support of vendors with strong ties and interests in the academic/research field who provide funding for ten of ACRL's 15 awards. The award juries are comprised of ACRL members appointed by either the ACRL president or the appropriate section's chair. The juries rely heavily on the ACRL membership to act as their eyes and ears in finding the truly commendable and outstanding of the profession.

Each award has a flyer (available on ACRL's homepage or from the ACRL office) that gives information on the award amount, criteria, submission procedures, and who to contact for assistance or questions. Members are strongly encouraged to make nominations or applications for these awards.

Most awards have a December 1, 1996, submission deadline.

The ACRL awards are listed below; sponsors are noted in parentheses.

\section{Achievement and distinguished service awards}

- Academic or Research Librarian of the Year Award (Baker and Taylor Books).
- Community College Learning Resources/ Library Achievement Awards (EBSCO Subscription Services)

- Marta Lange/CQ Award for Law Librarians (Congressional Quarterly).

- Miriam Dudley Instruction Librarian Award (Mountainside Publishing Company).

- Instruction Section Innovation in Instruction Award.

- Distinguished Education and Behavioral Sciences Librarian Award.

- Hugh C. Atkinson Memorial Award (ACRL, LAMA, LITA, ALCTS).

\section{Research awards/grants}

- Doctoral Dissertation Fellowship (Institute for Scientific Information).

- Samuel Lazerow Fellowship for Research in Acquisitions or Technical Services (Institute for Scientific Information).

- West European Specialist Study Grant (Martinus Nijboff International).

\section{Publications}

- Katharine Kyes Leab and Daniel J. Leab Exhibition Catalogue Awards (Katharine Kyes Leab and Daniel J. Leab American Book Prices Current).

- Rare Books and Manuscripts Librarianship Award (Christie, Manson and Woods).

- K. G. Saur Award for Best Article in CERL (Reed Reference/K.G. Saur).

- Instruction Section Publication Award.

- Oberly Award for Bibliography in the Agricultural Sciences.

\section{More information available}

More information on the awards is available on ACRL's homepage (http://www ala.org/acrl. html) under "Professional Development" or from the ACRL office. Contact: Jack Briody at (800) 545-2433, ext 2516, or jbriody@ala.org. 